\title{
"Mysteries of success for small and medium enterprises in Ga-Rankuwa Township of Pretoria in Gauteng Province, South Africa"
}

$\begin{array}{ll} & \text { Pabalelo Selaelo Maesela } \\ \text { Taurai Hungwe } \\ \text { Solly Matshonisa Seeletse }\end{array}$

Pabalelo Selaelo Maesela, Taurai Hungwe and Solly Matshonisa Seeletse

ARTICLE INFO (2016). Mysteries of success for small and medium enterprises in Ga-Rankuwa Township of Pretoria in Gauteng Province, South Africa. Environmental Economics, 7(1), 47-52. doi: 10.21511/ee.07(1).2016.06

DOI http://dx.doi.org/10.21511/ee.07(1).2016.06

RELEASED ON Thursday, 24 March 2016

JOURNAL "Environmental Economics"

FOUNDER LLC "Consulting Publishing Company "Business Perspectives"

NUMBER OF REFERENCES

0

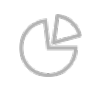

NUMBER OF FIGURES

0

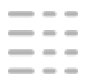

NUMBER OF TABLES

0

(C) The author(s) 2022. This publication is an open access article. 
Pabalelo Selaelo Maesela (South Africa), Taurai Hungwe (South Africa), Solly Matshonisa Seeletse (South Africa)

\title{
Mysteries of success for small and medium enterprises in Ga-Rankuwa Township of Pretoria in Gauteng Province, South Africa
}

\begin{abstract}
The small and medium enterprises (SMEs) are important to the South African economy and social development. This paper discusses the case of Ga-Rankuwa Township SMEs, causes of their proven failure and the methods used by the SMEs owned by people who came from foreign countries and operating in this township. These foreign SMEs did not have access to loans for business. On the other hand the local ones could apply for the loans but many did not know how and where. The locals then forfeited the opportunity, but still refused to partner with foreign ones who could assist them. The foreign ones were more successful in using business skills and knowledge to nurture their SMEs. They also contributed to the township's economy by employing local people. Recommendations include that local SMEs should partner with foreign ones to develop synergies, and that the SME agency, Small Enterprise Development Agency (SEDA) should design policies for foreign SME access to business loan funds by ensuring and enforcing local empowerment as part of their loan access package.
\end{abstract}

Keywords: business loans, failure, foreign SME, local SME, success, sustainability.

JEL Classification: D4, O1, O4, Q5.

\section{Introduction}

In the South African township residential areas, SMEs are usually small grocery stores that sell everyday small household items. The instability of locally-owned SMEs led to foreign entrepreneurs realizing an opportunity for competition. As a result, since 1994 when South Africa gained democracy, there has been SME competition between South African operators and immigrant run businesses (Liedeman, 2005). Research has sought to understand the dynamics of this competition and the impact of the apparent dominance of foreign-owned SMEs over their South African counterparts. According to Bear et al. (2005), the precise nature of the competitiveness challenge has been poorly understood.

The platform of competition favors local entrepreneurship. The South African government has encouraged the local entrepreneurs through enabling legislation. Entrepreneurial performance is based on starting a business and the utilizing an opportunity to grow the business idea by making profits. Generating money is the entrepreneur's target to gauge entrepreneurial performance and to claim achievement. Knowledge and skills are necessary for business success. Among others, business skills include being

(C) Pabalelo Selaelo Maesela, Taurai Hungwe, Solly Matshonisa Seeletse, 2016.

Pabalelo Selaelo Maesela, Department of Statistics and Operations Research, Sefako Makgatho Health Sciences University, South Africa.

Taurai Hungwe, Department of Computer Science, Sefako Makgatho Health Sciences University, South Africa.

Solly Matshonisa Seeletse, Professor of Operations Research, Department of Statistics and Operations Research, Sefako Makgatho Health Sciences University, South Africa. able to formulate business plans, financial management, marketing, operational management, human resources, legal guidelines, communication, as well as management skills for business operations (Ladzani \& van Vuuren, 2002). Entrepreneurial skills include creativity, innovation, risk-taking, and the ability to interpret successful entrepreneurial role models and identification of opportunities. This study compares foreign and South African entrepreneurs by drawing on case evidence from Ga-Rankuwa Township on the northwestern side of Pretoria city in the Gauteng Province of South Africa.

\section{Context and study problem}

South Africa's democracy of 1994 opened doors to many refugees and migrants who came into South Africa because of the emerging opportunities. Many foreigners spotted and embraced open opportunities of development. Among the opportunities they treasure is the availability of items they could use to start their own businesses. Currently, there is accessibility of cheap products of foreign run retailers in the country. In the townships, concerns so far raised include foreign take over of local SMEs. This is despite foreign entrepreneurs being celebrated in many countries for their contribution to economic growth and employment creation. In South Africa, the opposite appears to be true, as the ongoing violence against foreign run businesses shows lack of appreciation of foreigners by some South Africans (Ligthelm, 2005). Xenophobic attacks in which looting and attack of shops owned by the Somali, Pakistani, Malawian and other foreign nationals attest to this. The attacks and mistrust towards foreign shop owners started from jealousy when local- 
ly owned SMEs were closing down en masse while the foreign-owned ones were increasingly favored by many customers. This study attempts to determine how foreign entrepreneurs have become successful in their businesses. It is therefore important to evaluate the business models which foreign business owners use to succeed in their businesses. The objective of the study is to compare the business models of locally owned and managed SMEs with the foreign managed ones in Ga-Rankuwa. The study that was undertaken wanted an answer to the question: "Why are foreign SMEs more successful?"

\section{Literature review}

1.1. Business model. A business model is a plan for the successful operation of a business, identifying sources of revenue, the intended customer base, products, and details of financing (Kshetri, 2008). It describes a business operation through all its components, functions, and processes which result when cost for the model justifies value for customers. Morris and Pitt (1995) counsel that an attractive business model can be achieved in four ways. These ways are product (or service) differentiation, pricing, customer support and ensuring customer satisfaction. It can also be viewed as a plan for the successful operation of a business, identifying sources of revenue, the intended customer base, products, and details of financing.

In differentiating the product, a business should strive to develop a unique selling point. This is when a company does something different from its competitors, and even better to give the customers a reason to prefer their better product. This generally enables the differentiated product to earn superior profits. Entrepreneurs need to thoroughly understand the competition and effectively communicate the unique advantages of their products.

1.2. Pricing strategy. According to Amram and Kulatilaka (1999), a basic decision to make is how much to charge for the products on the market. For the business to survive, customers should be convinced that the price of a product represents value for money. Supporting the customers refers to making the product enjoyable. It could be by adding value to the items sold, and making other efforts to develop a trust with the customers. Having a truly successful business is based on one simple concept which is trust. Then, achieving customer satisfaction is the crucial goal of a business for success (Chapman \& Ward, 1997). The ultimate success of a business is based on the business mix which the business uses to make the customers cheerful.

1.3. Business practices in South African SMEs. Siphamandla (2008) undertook a study to determine the characteristics of ownership, the scope of employment within the business and trading practices of SMEs in townships of the Western Cape and Gauteng provinces of South Africa. An important finding was that South African owned SMEs were less competitive than foreign-run ones. The foreign ones' successes were attributed to the strength of their social networks, which provided them with access to labour and capital. These enabled them collective purchasing and market domination. The study also revealed a growing concern from local business owners that a sizeable proportion of the economic value generated within township SME market, including wages, was exported from the township economy to home countries of these foreign entrepreneurs and workers. A further concern was that foreign SMEs provided access to illegal imports. Five key business models that foreignowned SMEs used for their success in their businesses are explained below:

Ownership dynamics: Most South African SMEs were home-based, whereas foreign-run ones usually operated from rented premises usually an existing small retail shop venue (Simrie, Herrington, Kew \& Turton, 2012). Thus, houses restricted local SME activities and mired them. Another differentiating factor, even though its impact is not known, is that a significant number of South African owned SMEs were owned and run by women, whilst almost all foreign operated ones were male owner-managed businesses. Also, the foreign ones had collective or cooperative ownership among foreigners and the South African ones were sole traders.

Capital investment: The scale of investment by foreign-owned SMEs was approximately R45000 on average, within start-up businesses compared to R1500 to R5000 on average for South African SMEs. The financial backing from these ownership models combined with the benefits of an ethnic business networking enables foreign SMEs to purchase within buying collectives and achieve greater economies of scale (Van Vuuren \& Botha, 2010). The study reveals that this bigger purchasing power, together with lower unit transaction cost such as transport and labor, enables these collectives, similar to large enterprises, to secure more favorable terms from wholesalers and obtain direct supply linkages to manufacturers.

Stock procurement: A vital business advantage of foreign-owned SMEs lied in the semi-cooperative supply system through which they procured their goods from wholesalers and manufacturers (Abor \& Quartey, 2010). The foreign-owned SMEs successfully used supply chain networking and price discounting to procure goods more cost effectively. 
Each of these SMEs benefited from a procurement and distribution chain that supports multiple stores. As a result of their scale of operation, each buying collective could secure premium terms from suppliers, reduced transport costs and ensured that retailers within the group received an uninterrupted supply of merchandize. The South African sole trader SMEs were unable to match the collective purchasing power and labor advantages of the foreign businesses. Many of them then either closed their SMEs or focused only on commodities which they could sustain and enjoy some competitive advantage over others. Examples of the ones the South African SMEs kept were take-away food and liquor retailing.

Business operations: Locally owned SMEs operated on part-time bases to supplement household incomes. Most of them operated their SMEs themselves or drew on family labor. Foreign ones conducted theirs on a full-time basis and provided employment to persons other than the business owner and family. These employees were mainly casual workers. Some of these employees worked around the clock as shopkeepers during the day and security guards at night. This enables the foreign SMEs to minimize their labor costs, whilst employing sufficient staff to operate the business over longer trading hours. Many trade between 6 am and $10 \mathrm{pm}$.

Product diversification: One success factor of foreigners within the SME market was the careful positioning of SMEs to operate within particular niche markets (Amini, 2004). Product diversity and range had given foreign run SMEs competitive advantage while local entrepreneurs had neither diversified nor differentiated their products.

1.4. Typical structure of South African SMEs. South African SMEs include grocery retailing and house shops (Liedeman, 2013). Historically, many of them began as house shops selling few items, gradually evolving and changing form as they grew in size. Chebelyon-Dalizu and Garbowitz (2010) found that many SME owners lacked business management skills. Since many of the SMEs were created hastily, the owners dealt with many challenges such as lack of preparation and entrepreneurial dynamism. Another major SME challenge was financial weakness. Wholesalers were often refusing to give discounted prices to SME owners because they bought insufficient quantities of goods. As a result, SME owners had to pay same goods prices as their customers who often did shopping at the same wholesalers (Bear et al., 2005). Hence, in pursuit of making a profit, they had to sell their goods at higher prices. As large retailers offered goods at better rates, the SMEs lost business.
These SMEs also lacked consistent distribution systems to get the goods from suppliers to their shops. Some major companies delivered products to SME premises directly, but most would not. There were also independent distributors that some SMEs could hire to deliver goods to their premises. However, many SMEs had to go and buy their goods themselves. Since many did not own their own cars, they would often take a bus or a taxi to get to their supplier, pick up goods, and carry all those goods on public transportation back to their business premises (Bear et al., 2005).

Many SME owners struggled to obtain business loans. South African banks were overly cautious about lending money to SMEs (Department of Trade and Industry, 2009). Also, they received vague information when they were refused loans. Banks seemed to be uninterested in dealing with them.

1.5. Contrasting local with foreign SMEs, using Somali SMEs. Liedeman (2005) compared South African and foreign-run SMEs. He found the business approaches and operations contrasting significantly. An important difference was the role of social networks. With the Somali SMEs, clan-based social networks played a crucial role in enabling competitive business models. The networks provided various services, including access to cheap labor from Somalia; enforcement of contractual agreements by the network, with clan elders overseeing business deals; strategic investment in geographical areas to establish Somali strongholds; group purchasing to secure discounts and operational economies of scale; and facilitating microfinance by organizing investments and business partnerships (Jauch, 2010).

Foreign SMEs generally tried their best to succeed, and with little or no waste as they usually would have no backup if they lose. As a result, Somalian SMEs dominated foreign SMEs. The role that a social network played for the Somalis was noticeable in many ways of conducting business in townships. Foreigners combined with family, clan members and friends by pooling their money and buying in bulk (Liedeman, 2005). As a result, they reduced costs of goods purchased. This transformed into a competitive advantage. Hatten (2015) explains that Somali SME's success was based on low mark-ups, high stock volumes, long hours and willingness to give credit to trusted customers.

\section{Methodology}

A qualitative study was conducted to establish the way SME owners in Ga-Rankuwa Township managed their businesses. A convenience sample of SME owners was chosen. The tool for data collection was a questionnaire. The SME owners were 
located and requested to participate. Only those willing to participate were targeted. Fifty questionnaires were distributed to them. A total of 41 came back, but only 36 were used because others were incomplete or unclear. A comparative analysis of local SME owners and foreign owned ones was done by applying descriptive statistical methods to analyze the data set collected. Descriptive statistics provided summaries about the samples (Baron \& Shane, 2008). In this study these were the mean, median, mode, standard deviation, minimum and maximum values. The SPSS statistical package was used in the analysis.

\section{Results}

The 36 surveyed SMEs showed to be successful. Their minimum working hours were 10 and maximum were 17 with 13.6 hours average, 14 hours mode, 14 hours median, and 1.3 hours standard deviation. Some had someone working for their SMEs up to a maximum of four with a mean of $1.4 \mathrm{em}-$ ployees, median of 1.5 employees and mode of 0 employees, and standard deviation of $1.36 \mathrm{em}-$ ployees. Specifically, all the Malawi and Pakistani SMEs had employees working for them. No Mozambican SMEs had employees, 67\% of Zimbabwean ones had employees, $44 \%$ of Ethiopians had employees, and 38\% of Bangladeshi SMEs had employees. For South Africa, 57\% ohad employees.

Foreign SME owners worked in their SMEs, and looked after their businesses. They monitored and controlled their SME activities. They worked onsite, on a full time bases and managed their SMEs the way they wanted them. On the contrary, the local SME owners worked on part time bases, and employed someone to manage their SMEs. They also lacked monitoring and control systems for their SMEs.

Huge amounts of money generated in the SMEs seemed to have been sent out of the country to the homes of these foreign SME owners. However, the exact amount or proportions of profits could not be ascertained. This was due to loose regulation of South African SMEs.

This study could not secure any Somali SMEs. Ethiopian SMEs dominated the market share with 25\%, Bangladeshi's with 22\%, and Pakistani's and South Africa's were at $19 \%$ each. Minority market shareholders were from Zimbabwe with 8\%, and Malawi and Mozambique each with 3\%. Among the foreignowned SMEs, the Asians (Pakistan \& Bangladesh) dominated at about $41 \%$, and Africans (Ethiopia, Malawi, Mozambique \& Zimbabwe) had about 39\%. The SMEs seemed to be financially stable. Also, the local consumers did most business with foreign SMEs due to cheaper prices and better treatment.
Most (36\%) SMEs had been existing for one to two years old; followed by $31 \%$ who had existed for three to five years old. The six to 10 years old SMEs made $17 \%$ and the 11 to 20 years old ones also made $17 \%$.

Of all these SMEs, $81 \%$ were not born in South Africa. About $8 \%$ had owned an SME in Ga-Rankuwa for one to two years, $36 \%$ for three to five years, $22 \%$ for six to 10 years and $33 \%$ for 11 to 20 years.

Only the South African SMEs were qualified to apply for business loans. However, many did not know where to apply, and even how to apply. Moreover, the local SMEs did not support one another, and did not partner to assist in finding synergies. Some foreign ones approached financial institutions and were turned down on the basis of being non-South Africans. Also, there was a training course for registered South African SMEs administered by Seda (Small Enterprise Development Agency). They also did not know about it, and thus did not apply.

On exploring more foreign SMEs had an option to obtain funding by forging links with South Africans. Some of them approached the locals for partnerships but were turned down. Moreover, some locals showed some hostilities towards foreign owned SMEs.

The foreign-owned SMEs marketed their SMEs, and showed astute management skills, showed advanced management styles, seemed to have understood consumers' social problems (e.g., they gave credit to loyal customers only), and nursed human resource problems (they employed a local person), among other qualities. They did not show to have financial problems for business, and their SMEs showed to be successful. Lastly, $86 \%$ of SMEs' start-up capital came from own savings of the owners.

Refusals by locally-owned SMEs to partner with foreign ones had drawbacks. One pitfall was denying local communities more businesses and more employment. Hence, this was an economic opportunity not explored. Also, the locals could have benefited by accessing the funds. The SME owners from foreign origin knew where and how to access business loans. However, they did not qualify to apply. Their partnerships with locals could have assisted both parties.

The foreign-owned SMEs attracted the market in the way that Morris and Pitt (1995) had suggested. These are by differentiation, pricing, customer support and customer satisfaction from which trust develops.

\section{Discussion}

Personal sacrifices of long hours and saving money for capital; as well as knowledge and skill in business management, human resources, marketing, finances, business management, among others, underlie the beginning of SME success. They stocked 
in bulk, saving costs of acquiring stock. The strategies they used were partnering with other SMEs. The partnering SMEs also supported one another in their businesses. These features were mostly found in foreign-owned SMEs, but less in South Africanowned ones.

Only the local SMEs were qualified to apply for business loans. However, many of them did not know how and where they could apply. This means that they did not know about the advantage they had if they had worked with foreign counterparts. As a result, it did not benefit them. They also did not know about available SME supports that were open to them.

The local SMEs offered few/limited items, stocked few items and forfeited wholesale discounts, were sometimes not stocked, and were more expensive. A worse case is that the locals did not realize the synergies possible with the option of merging with foreign ones. These synergies could have emerged from securing loans (foreigners benefitting from local advantage) and business management education (locals benefitting from foreign SME knowledge advantage). These could not happen without partnering.

The sustained and successful SMEs cared for the locals, and also sold only to the loyal customers on credit. Their products were also cheaper. The SMEs employed local people. With the recently increased GaRankuwa unemployment rate, the SMEs were making an economic contribution in the township. Only few foreign SMEs had not employed anyone though.

\section{Conclusion}

The foreign SME owners worked and sacrificed harder, approached their businesses more wisely, and used modern methods in conducting their businesses. Also, the partnerships they formed were beneficial to the foreign SMEs. The cheap prices of stock from these partnerships, as well as the partners augmenting one another, gave the foreign-owned SMEs a position of strength in competition. These approaches were not followed by the locals. The locals did not take the advantage of loans to secure funding. They competed with the foreign SMEs from a position of weakness.

The local SME owners did not demonstrate to have vision in their business, and seemed to be fixated in jealousy. They started small and only thought of participating at a low scale with no conscious intent to expand. Also, they seemed to have been xenophobic against their foreign counterparts. There was more worry that foreign SMEs were growing than the concern of their own SMEs becoming successful. Stocking low quantities and paying high prices did not bother them, and they could not even realise these as part of their downfalls. As a result, they forfeited chances to benefit from connections with foreign SMEs. Their approaches to business ownership also seemed to be unplanned.

Consumers continued to use foreign SMEs for cheaper prices and good service. The local SMEs continued to fail and be unsustainable. The foreign ones continued to grow strong, and they also employed the local people despite their small sizes and funding scarcity. There was still a need for local SMEs to develop and grow, but the foreign ones should be supported to contribute to the local economy.

\section{Recommendations}

The Seda initiative should extend to encourage local SMEs to partner with local ones in order to access the loans, augmented skills and market knowledge, and increased business sizes. This agency can also open up to foreign SMEs with clear and specific conditions of empowerment of the members of the local community.

The Department of Trade and Industry as the regulatory department should ensure that the riches generated by the foreign SMEs are regulated properly and not as loosely. Amounts exported should be restricted. There should be a portion regulated for allocation to local development and spending. Taxes should also be paid when permitted to conduct business in the country.

The local SMEs should consider growing by working hard (long hours, bulk stock purchases), sell at lower prices, support one another cleverly. They should ensure that their SMEs have effective monitoring and control systems. They should also consider partnering with foreign SMEs for mutual development.

Ga-Rankuwa SMEs should consider learning business skills. However, due to time and financial constraints, their quicker beneficial ways are to partner with progressive foreign SMEs. In this way they can learn to access loans, and to learn some business skills.

\section{References}

1. Abor, J. \& Quartey, P. (2010). Issues in SME development in Ghana and South Africa, International Research Journal of Finance and Economics, 39, pp. 219-228.

2. Amini, A. (2004). The distribution role of small business in development, International Journal of Social Economics, 31(4), pp. 370-383.

3. Amram, M. \& Kulatilaka, N. (1999). Real options. Harvard Business School Press. 
4. Baron, R.A. \& Shane, S.A. (2008). Entrepreneurship: a process perspective, $2^{\text {nd }}$ edition. Ohio: Thompson SouthWestern.

5. Bear, M., Bradnum, P., Tladi, S. \& Pedro, D. (2005). Making retail markets work for the poor - why and how Triple Trust Organization decided to intervene in the spaza market in South Africa. Washington, D.C.

6. Chapman, C. \& Ward, S. (1997). Project risk management. New York: John Wiley \& Sons.

7. Chebelyon-Dalizu, L., Garbowitz, Z., Hause, A., Thomas, D. (2010). Strengthening spaza shops. WPI. Available at: http://wp.wpi.edu/capetown/homepage/projects/p2010/ spaza.

8. Department of Trade and Industry. (2009). South African trade statistics [homepage on the Internet]. Available from: http://www.dti.gov.za/econdb/raportt/rapmenu1.html [visited on 17 September 2015].

9. Hatten, T.S. (2015). Small business management: Entrepreneurship and beyond. London: Cengage Learning.

10. Jauch, H. (2010). The role of SMEs in employment creation and economic growth: Lessons from other countries. A response to Neil Ramsden. Windhoek: Bank of Namibia.

11. Kshetri, N. (2008). Barriers to e-commerce and competitive business models in developing countries: A case study, Electronic commerce research and applications, 6(4), pp. 443-452.

12. Ladzani, W.M. \& Van Vuuren, J.J. (2002). Entrepreneurship training for emerging SMEs in South Africa, Journal of Small Business Management, 40(2), pp. 154-161.

13. Liedeman, R. (2013). Understanding the internal dynamics and organization of spaza shop operators: A case study of how social networks enable entrepreneurialism amongst Somali but not South African traders in Delft South, Cape Town.

14. Ligthelm, A.A. (2005). Informal retailing through home-based micro-enterprises: the role of spaza shops, Development Southern Africa, 22(2), pp. 199-214.

15. Morris, M.H., \& Pitt, L.F. (1995). Informal sector activity as entrepreneurship: insights from a South African township, Journal of Small Business Management, 33(1), pp. 78-86.

16. Simrie, M., Herrington, M., Kew, J. \& Turton, N. (2012). Global Entrepreneurship Monitor: 2011. Cape Town: South African. Centre for Innovation and Entrepreneurship, University of Cape Town.

17. Siphamandla, Z. (2002). Xenophobic attacks: towards an understanding of violence against African immigrants in South Africa, Africa Insight, 38(2), pp. 26-35.

18. Van Vuuren, J. \& Botha, M. (2010). The practical application of an entrepreneurial performance training model in South Africa, Journal of Small Business and Enterprise Development, 17(4), pp. 607-625. 